\title{
Puppet Master
}

Somehow I am chased away And I slowly lose faith in me Somehow I'm a waste today No one tells me who to be

The script erased my lines I don't know how to shine But the stage was my throne How do I run the show alone

Drowned in my tangled strings

Like I'm tied to my demise And all that this illusion brings I've become what I despise Can't find what I lost long ago Which puppet master runs the show Now how do I run the show alone How do I run the show alone

Sometime soon I should break free And I wish for that loose wire Sometimes I feel that fire in me No one knows what I desire

The script erased my lines I don't know how to shine But the stage was my throne How do I run the show alone 
Drowned in my tangled strings

Like I'm tied to my demise

And all that this illusion brings

I've become what I despise

Can't find what I lost long ago

Which puppet master runs the show

Now how do I run the show alone

How do I run the show alone

I'm scratched and desecrated

Lost in a blink of an eye

Attached and manipulated

Caught in the chaos of life

I'm hurt that I have to admit

Don't know how to say goodbye

Why am I no longer passionate

And why don't I even try

Drowned in my tangled strings

Like I'm tied to my demise

And all that this illusion brings

I've become what I despise

Can't find what I lost long ago

Which puppet master runs the show

Now how do I run the show alone

How do I run the show alone

Koen van der Heide 